\title{
Of bees, birds, trees, and women: iconography, superstition and victimization of female characters in Yugoslav New Film
}

\author{
VESI VUKOVIĆ \\ Film Studies and Visual Culture \\ University of Antwerp, Belgium
}

\begin{abstract}
Vuković Vesi, Of bees, birds, trees, and women: iconography, superstition and victimization of female characters in Yugoslav New Film. "Images" vol. XXVIII, no. 37. Poznań 2020. Adam Mickiewicz University Press. Pp. 285-307. ISSN 1731-450X. DOI 10.14746/i.2020.37.16

This study investigates how the directors of two selected case study films criticise the real-life remnants of patriarchy in the family sphere, in nominally gender-equal Yugoslavia. I argue that they do this by transposing their stories from socialist Yugoslavia to the pre-socialist times: during Ottoman rule and monarchist Yugoslavia. The selected period films Breza/The Birch Tree (Ante Babaja, 1967, Yugoslavia) and Roj/The Beehive aka The Swarm (Miodrag 'Mića' Popović, 1966, Yugoslavia), both belonging to the Yugoslav novi film (New Film) movement (1961-1972), refract the workings of the vestiges of patriarchy in a family domain of Yugoslav socialist society. In these two costume dramas, patriarchy is portrayed to its fullest extent, due to their stories being set in the past, ostensibly unrelated to contemporary Yugoslav society and thus uninhibited by the drive to cater to the official discourse of female emancipation.

Applying a critical film feminist perspective, by formal analysis via close readings of these two selected films, this article examines the iconography linked to fictional depictions of heroines and delves into the representation of victimisation of women. I investigate whether the depiction of the female sorceress(es) embody the primitiveness, ignorance, and/or poverty of economically disadvantaged and historically oppressed pre-socialist village. In order to peruse not only the individual portrayal of female protagonists but the dynamics of their interaction, the Bechdel test is applied and complemented with concepts such as the 'reversed masquerade' and 'cryptomatriarchy', which sheds light on the relationship between women and the presence or absence of female solidarity.
\end{abstract}

KEYwORDs: iconography, Yugoslav New Film, female characters, Bechdel test, 'reversed masquerade', 'cryptomatriarchy'

The main aim of this study is to investigate why the directors of two selected Yugoslav New Films depict the patriarchal reign of a pre-socialist past, instead of their socialist present. Why did they choose to feature women as the main characters, which was less common in the Yugoslav novi film (New Film) Movement? I propose the argument that this was a choice to criticise the real-life remnants of patriarchy in the family sphere of a nominally gender-equal Yugoslavia, by cinematically regressing into the past, into the pre-socialist times before the Second World War, instead of showing the socialist present of the 1960s. In the two studied costume dramas, patriarchy is portrayed in its fullest extent, due to the stories being set in the past during Ottoman rule and monarchist $\mathrm{Yu}-$ goslavia. The films are ostensibly unrelated to their contemporary Yugoslav society and are thus uninhibited by the inclination to cater to the official discourse of female emancipation. The Yugoslav socialist state took all the necessary legislative measures for guaranteeing and promoting gender equality. What it could not fully eradicate were the patriarchal mindsets of people in the domain of the family, dating back and persisting from pre-socialist times. By having a critical attitude towards myths of 
the past, films are critically relating to their contemporary myths. [1] Therefore, I contend that the selected period films, Breza/The Birch Tree (Ante Babaja, 1967, Yugoslavia) and Roj/ The Beehive[2] aka The Swarm (Miodrag 'Mića' Popović, 1966, Yugoslavia), both belonging to the Yugoslav New Film movement, refract the workings of the vestiges of patriarchy in a family domain of Yugoslav socialist society. I observe the films from a critical film feminist perspective, by formal analysis via close readings.

In addition, my study scrutinises the represented victimisation of women, and the meanings behind iconography (of the birch tree, the white dove and the queen bee) linked to fictional depictions of heroines. In order to observe and analyse, both the individual portrayal of female protagonists and the dynamics of their interaction, the Bechdel test is performed. Although initially originating as a witty insight from a comic writer and not meant to be employed as a method to investigate the silencing

[1] S. Novaković, Vreme otvaranja, Novi Sad 1970, p. 152.

[2] Although the more accurate literal translation of the film title would be The Swarm, which appears in few rare mentions of the film by other authors, I decided to translate it as The Beehive, because it better captures the essence of the film in terms of the iconography of the bees.

[3] J. O'Meara, What "The Bechdel Test" doesn't tell us: examining women's verbal and vocal (dis) empowerment in cinema, "Feminist Media Studies" 2016, 16 (6), p. 1120.

[4] M. Bogojević, The beauty of gender sin: politics of representation in Yugoslav auteur film, "ProFemina" 2011, pp. 255-262.

[5] A. Simić, Machismo and cryptomatriarchy: power, affect, and authority in the traditional Yugoslav family, [in:] Gender Politics in the Western Balkans, ed. S.P Ramet, University Park 1999, pp. 11-30.

[6] M. Bogojević, The beauty of gender..., p. 259.

[7] A. Simić, op.cit., pp. 67-77.

[8] S. Slapšak, Žensko telo u jugoslovenskom filmu: status žene, paradigma feminizma, [in:] Žene, slike, izmišljaji, ed. B. Arsić, Beograd 200o, p. 128. [9] Ibidem.

[10] Ibidem. of female characters in films, in recent years the test has often been applied to cinema for evaluating gender representation.[3] The shortcomings of the somewhat over-simplified Bechdel test are complemented with concepts such as the 'reversed masquerade', [4] and 'cryptomatriarchy', [5] which shed light on the relations between women and the presence or absence of female solidarity. The former theoretical concept refers to the celluloid effaced femininity of elderly women, often clad in black, who appropriate patriarchal attitudes from their male family members and use manly behaviour as a mask.[6] The latter concept implies the hidden, obscured power of elderly women within a real-life household of a patriarchal family, specifically regarding younger women.[7] Lastly, I foreground how, in the selected films, a female sorceress embodies the primitiveness, ignorance, and poverty associated with the economically disadvantaged and historically oppressed pre-socialist village.

The reason for selecting and analysing The Birch Tree and The Beehive is due to both being period films set during pre-socialist times. The Birch Tree takes place in the era between the two World Wars, during the Kingdom of Yugoslavia, thus regressing into the times of tradition when patriarchy reigned. Similarly, The Beehive evokes bygone times in the more distant past of the First Serbian uprising against the Ottomans in 1804. Moreover, these two case study films were chosen due to both being shot in the times of socialism, when gender equality was proclaimed. The thematic distancing from current events in the socialist present by placing the story in the past, accentuated by the usage of costumes and settings, renders any ideological obligation towards the socialist state unnecessary.[8] Consequently, it enables a subtlety in audio-visual or narrative character development.[9] In contrast, gender representations as stereotypes are more frequent in Yugoslav films which deal with contemporary themes. [10] This is the case in many Yugoslav New Films, which makes the two analysed films belonging to this movement rather exceptional, since they feature 
fleshed out female characters and stories set in the pre-socialist past.

Jovanović[11] notes that some films classified as the Classical Yugoslav Cinema (generally speaking, films with classical narrative preceding the Yugoslav New Film movement) were critical of the rural patriarchal tradition as a part of earlier times, while simultaneously implying that it might still be present in $\mathrm{Yu}-$ goslav socialist society. Focusing on gender whilst peasant-themed, they initiated a debate on the patriarchal legacy of traditional rural life, stretching from the pre-socialist era into socialism, to some extent.[12] My argument is in line with Jovanović's, since The Birch Tree and The Beehive elicit this kind of debate. Thus, there is a continuity of the Classical Yugoslav Cinema with Yugoslav New Film, which 'constantly destroys all existing societal myths and questions traditional values of one patriarchal moral'.[13] Therefore, drawing on Slapšak's, Jovanović's and Novakovićs views, I contend that in the case study films, directors Babaja and Popović criticised the real-life gender imbalance in the family domain of socialist Yugoslavia by portraying the workings of patriarchy, as set in the past.

\section{Yugoslav new film and gender}

Both analysed films belong to Yugoslav New Film, a loose auteurist movement without a manifesto, which Dušan Stojanović bookends between 1961 and 1972.[14] Yugoslav New Film tackles themes in an innovative manner, exhibits modern aesthetic tendencies in its form and is often in opposition to Yugoslavian traditional narrative film,[15] a formally and thematically mainstream cinema that coexisted alongside it. Divergent in their styles, Yugoslav New Film directors sought an authentic connection not only to the topic they explored, but to the viewers as well.[16] The unifying threads of the movement include social criticism, a more open attitude towards sexuality, and a pessimistic outlook on life.[17] In addition, the depiction of generational conflict is one of the traits of Yugoslav New Film, which, generally speaking, is shared with the other initial 'new waves' that developed in several countries, such as French Nouvelle Vague, Japanese Nūberu bāgu and Czechoslovakian Nová Vlna.

Aside from the presence of generational conflict, the two selected films also qualify as Yugoslav New Films for being innovative and prone to experimentation in terms of content, and style. They are both rather formally stylised, with non-linear narrative structures. Subsequently, their editing is complex and interspersed with retrospective scenes, which could be another argument (but not exclusive) for categorizing them as Yugoslav New Films, as opposed to the mainstream films with mostly invisible, linear editing and classical narrative dramatic structure. The formal characteristics of Yugoslav New Film are suffused with absolute stylistic freedom, where every auteur freely choses means of expression that suit him[18] best.[19] The somewhat theatrical The Beehive has powerful black and white photography by Milorad Marković, whilst The Birch Tree - perhaps visually one of the most highly regarded Yugoslav films - is shot in colour by director of photography Tomislav Pinter. Babaja seeks a classical beauty within his images, while simultaneously being entirely modern thematically, with the fact that he touches upon unexplored spheres of social politics and bodily

[11] N. Jovanović, Gender and Sexuality in the Classical Yugoslav Cinema, 1947-1962, PhD, Gender Studies, Central European University 2014, p. 182.

[12] Ibidem, p. 225.

[13] S. Novaković, op.cit., p. 76. Own translation.

[14] A. Petrović, Novi film II (1965-1970): "Crni film", Beograd 1988, p. 355.

[15] D. Stojanović, Velika avantura filma, Beograd 1969, p. 158.

[16] Makavejev in: S. Novaković, B. Tirnanić, Dušan Makavejev: Negirati estetiku u korist života, "Polja" 1967, 13 (109), p. 6.

[17] A. Petrović, op.cit., pp. 329-349.

[18] Yugoslav New Film directors were mostly men.

[19] Makavejev in: S. Novaković, B. Tirnanić, Dušan Makavejev: Negirati estetiku u korist života, "Polja" 1967, 13 (109), p. 6. 
transience.[20] His first feature length fictional film Carevo novo ruho/The Emperor's New Clothes (1961), based on the tale by Hans Christian Andersen and set in an undefined past, is a critique of any rule, possibly even including that of Yugoslav President Josip Broz Tito. Keeping that in mind, it is not surprising that Babaja's next film The Birch Tree - which, as Gilić notes, was inspired by two novels written by Slavko Kolar in the interwar period[21] - is set into the past in order to comment on the contemporary issues of that socialist present. This aspect is common in both of the aforementioned films.

Namely, Babaja addresses the precarious position of a woman in a rural environment, specifically as she differs from the collective as an individual, whether with her fragile body or otherwise. Popović, a painter by vocation, also has a streak of social criticism in his artistic opus, both in his paintings and films. Pursuing social equality, 'his films would confront the past and the present of Yugoslavia..[22] Popović's and Babaja's work are in line with the definition of Yugoslav New Film as a movement tackling 'socio-national themes in a highly gendered mode, contrary to earlier propagandist films which systematically effaced gender for the sake of class (communist, patriarchal) struggle.'[23]

[20] Ibidem.

[21] N. Gilić, Uvodna bilješka, "Hrvatski filmski ljetopis" 2010, 16 (62), pp. 6-7.

[22] N. Miller., The Nonconformists: Culture, Politics, and Nationalism in a Serbian Intellectual Circle, 1944-1991, Budapest 2007, p. 152.

[23] M. Bogojević, op.cit., p. 257.

[24] M. Boglić, Mit i antimit, Zagreb 1980, p. 124.

[25] Ibidem.

[26] Ibidem, p. 123.

[27] Ibidem.

[28] P. Krelja, Breza - film za sva vremena, "Hrvatski filmski ljetopis” 2010, 16 (62), p. 19. Own translation.

[29] Ibidem, p. 19. Own translation.

[30] G. De Cuir Jr., Partisan "realism": representations of wartime past and state-building future in the cinema of socialist Yugoslavia, "Frames Cinema Journal" 2013, p. 3.
However, as Yugoslav film critic Boglić[24] notes, in modern Yugoslav New Film, a woman takes secondary place since the films of the directors who inaugurated this new wave, such as those of Aleksandar Petrović, Vatroslav Mimica, Zvonimir Berković, Matjaž Klopčić, and Babaja, primarily gave agency to a male hero as the subject of the action. In their films, the female character is often a passive object, stripped of her independence and equality.[25] Nevertheless, there were also a few real heroines, for instance: the mother queen bee Stojanka (Mira Stupica) in The Beehive by Popović; the wife of Hasan bey in Hasanaginica/Kameni despot ili jedna mogućnost narodne pesme Hasanaginica (1967) by the same director; or the mother in The Wild Growth/Samorastniki (1963) by Igor Pretnar.[26] However, many more were women-objects, who only watched as their destiny unfolded, tragically constrained by the mores of their society. [27] A typical example of female characters from that era of Yugoslav film, due to 'her passivity, certain helplessness and utmost dependence on a man'[28], is the much-mistreated Janica (Manca Košir), from Babaja's The Birch Tree. Yet, in contrast to Boglićs aforementioned critique of Babaja's woman-object, Krelja perceives it as a quality that regardless of whether Janica is dead or alive, the plot of the film revolves around her 'as opposed to the extreme marginalization of other heroines in so many fiction films from this region'. [29] Therefore, the focus on women as main characters makes The Birch Tree and The Beehive worthy of attention.

After viewing 269 films, out of 286 both mainstream and Yugoslav New Films, directed by Yugoslav directors from 1961 until 1972, I find that what many Yugoslav New Films share is a physical or symbolical harm, self-harm, neglect or control directed at female characters. Since Yugoslav New Film is frequently perceived as liberated, as De Cuir observes, it is ironic that female characters were usually portrayed as victims, who 'were often mistreated, abused, and even murdered'.[30] Modern Yugoslav New Films, in Boglićs view, are mostly 'male' films, which show all that is conservative 
in female nature, and all the negative excesses of somewhat more nominal than effectuated Yugoslavian real-life gender equality.[31] Oscillating somewhere between myth and the degradation of a fetishized female character, with more frequent tendency towards the latter, these films are often one-sided.[32] This is because they show only extremes or societal blackness, without depicting nuances or the other side of a past contemporary Yugoslav society, with numerous possibilities offered to Yugoslav working woman. Consequently, her reality with its complexities of both advantages and shortcomings does not exist in those films.[33]

Krelja notes that a common denominator of Yugoslav New Film auteurs is a similar outlook on a woman and her body. [34] On the one hand, a female character is often represented as bearing a significant part of the guilt that the world is not a better place to live in, due to carrying a seed of evil, being infected with weaknesses of society, or having a tendency towards infidelity. [35] Thus, a woman is the cause of a man's doom, and in turn a man consequently rapes or murders her.[36] Yugoslav New Film auteurs frequently (and wrongfully) attributed significant vices of reality to a woman in their intent to approach film as a conscience of society, as if she herself was personification of reality and life.[37] On the other hand, in cases when a female character is portrayed as morally decent, she is perceived by a male character, or even the entire environment, as a passive object suitable for inhumane treatment, and is submitted to individual degradation. [38] Therefore, from Krelja's observations, it can be deduced that in Yugoslav New Film, a woman and her body is, generally speaking, either a source of wickedness or a target for male vice, which results in her mistreatment.

Depictions of sexuality and gender in the context of Yugoslav New Film, and the attitudes of its directors towards gender norms, are yet to be acknowledged as one of its main traits.[39] Considering that Yugoslav New Film is dominated by male directors and mostly features men as the lead characters, the mere shift of focus on women as the main protagonists in the two selected films is attention worthy. Moreover, they are fleshed-out characters, as opposed to many Yugoslav New Film depictions of women as stereotypes. Aside from the fact that Babaja and Popović criticise the patriarchal behaviour towards the depiction of female characters, they are also occasionally complicit in, or have ambivalent viewpoint on, the matter of gender asymmetry.

\section{Gender equality in Yugoslavian socialism and representations of gender}

In order to ascertain whether there is a correlation between the analysed films set in the past and a seeming misalignment with gender issues in the Yugoslav socialism of the 1960s, I look into Yugoslav legislation. In Yugoslav society, gender equality was first legally enforced by the constitution of 1946. [40] All subsequent constitutions have continued to enforce it but, most importantly for this paper, the socialist state actively propagated it.[41] The Socialist State overtly and clearly let it be known that gender equality was a reward for active participation in the Second World War (as Partisan fighters, nurses, and civilians who supported the struggle by bringing supplies in the rear of

[31] M. Boglić, op.cit., p. 125.

[32] Ibidem.

[33] Ibidem.

[34] P. Krelja, Opake žene jugoslavenskog filma,

[in:] Knjiga o filmu: "Filmska kultura", 1957-1977, ed. F. Hanžeković, S. Ostojić, Zagreb 1979, p. 412.

[35] Ibidem, pp. 409-412.

[36] Ibidem.

[37] Ibidem, p. 413.

[38] Ibidem, p. 412.

[39] 2015. "Black Waves, Red Horizons - New Yugoslav Film”. Arsenal: Institut für film and videokunst e.V., accessed March 04.

[40] A. Zaharijević, The Strange Case of Yugoslav Femiism: Feminism and Socialism in "the East", [in:] The Cultural Life of Capitalism in Yugoslavia: (post)socialism and its other, ed. D. Jelača, M. Kolanović, D. Lugarić, Cham 2017, p. 266. [41] Ibidem. 
battlefield).[42] Women were granted legal benefits, such as the political rights to vote and to be elected to political bodies.[43] Furthermore, they gained rights to one year-long paid maternity leave, health insurance, access to education, freedom of choice, equal pay, marriage and divorce rights.[44]

The aforementioned aspects reveal, if the causes of gender-based discrimination towards women in the family domain were to be investigated, that the laws were not the source of it, on the contrary, they prevented it,[45] thus being, at the time 'some of the most progressive legislation in the world on women'.[46] They gave Yugoslav women 'by far more rights than American and Western European women'.[47]. The so-called 'women's question' was considered as resolved because, according to the state rhetoric, with the abolition of class that took place, and

[42] V. Gudac-Dodić, Položaj žene u Srbiji (194520oo), [in:] Žene i deca: 4. Srbija u modernizacijskim procesima XIX i XX veka, ed. L. Perović, Beograd 2006, p. 34.

[43] Ibidem.

[44] M. Morokvašić, Being a woman in Yugoslavia: Past, present and institutional equality, [in:] Women of the Mediterranean, ed. M. Gadant, London 1986 , p. 125.

[45] V. Gudac-Dodić, op.cit., p. 45.

[46] M. Morokvašić, op.cit., p. 125.

[47] A. Zaharijević, 'Women's Liberation', Četrdeset godina kasnije, "ProFemina" 2011, p. 195. Own translation.

[48] L. Sklevicky, Konji, žene, ratovi, Zagreb 1996, p. 89.

[49] M. Morokvašić, op.cit., p. 120.

[50] Ibidem, p. 127.

[51] Ibidem, p. 121.

[52] Ž. Papić, Žarana Papić. Tekstovi 1977-2002.

Belgrade 2012, p. 105.

[53] Z. Lóránd, The Feminist Challenge to the

Socialist State in Yugoslavia, Cham 2018, p. 124.

[54] I. Pantelić, Partizanke i antifašistički front

žena Jugoslavije (1942-1953), "ProFemina" 2011, p. 91.

[55] M. Đorgović, A. Panić, U. Popović, Ženska Strana/Women's Corner, [in:] Exhibition Catalogue, Belgrade 2010, p. 17.

[56] M. Morokvašić, op.cit., p. 133. legal and political reforms, gender inequalities were expected to consequently disappear.[48] Socialism indeed triggered a substantial improvement in women's rights, but on the other hand, it failed to fully keep the promise of their liberation.[49] Despite being empowered by employment, Yugoslavian women performed a second, unpaid shift in their own homes after coming back from work, by doing child-rearing and household chores, in most cases unaided by their husbands.[50] Thus, 'in the private sphere, legislation was unable to resist the old values and replace them with something new'.[51]

Reproducing the remnants of patriarchal mentality and their stereotypes in regards to the position and the role of women, mass media reinforced the ideal of a capable, hardworking, family-oriented housewife who does not leave the domestic sphere.[52] Both in everyday life and in the popular press, Yugoslav women gradually ceased to be represented as Partisan fighters and were left as happy housewives or worker women at the conveyor-belt'.[53]

The words of Tito were also in line with this trend. At the Third Congress of the Antifascist Front of Women (AFW), a communist women's organisation, he spoke about 'the specific duties' of women, such as nurturing and caring, especially for children.[54] Moreover, he mentioned how mothers dedicated to child-rearing should be perceived accordingly as the ones building socialism and performing socially-useful work, 'because proper raising of children is their first obligation'.[55] Furthermore, books also peddled disparate values for women and men. A study published by Rajka and Milan Polić in 1979 on the representation of female characters in schoolbooks for children, like corresponding studies made in France or Great Britain, concludes that 'there are fewer female characters in the books, women have the stereotyped roles of mother, housewife, nurse or teacher, and they are given more negative traits than boys.'[56]

Women were not only underrepresented numerically as the main characters in the schoolbooks ( 32 percent women, 68 percent men), 
but the roles they performed and the meanings ascribed to their portrayals also differed, thus socialising them to become maternal and indecisive, and to pay excessive attention to their own looks. [57] Consequently, the socialist state's implementations of gender equality and female empowerment were 'constantly being hindered by the values transmitted by the mass media and upheld by the old patriarchal system.'[58]

In his study of Yugoslav cinema in the 196os, Davor Beganović[59] notes the role of images to represent, while simultaneously affecting the ideological and political situation in a particular society. The idea that films not only reflect, but actually create meanings at the societal level, can also be borrowed from Paolo Favero's observation on Italian cinema, which is that certain 'films share a capacity to promote an image.'[60] Considering that not only in Yugoslav New Films, but even in mainstream films, depictions of gender equality were rare, especially in contemporary themed films, they concurrently refracted and promulgated an image of a subjugated woman. However, this is in contradiction to the official stance of the Yugoslav socialist state to endorse gender equality. Significant efforts were made to legally enforce emancipation of women, which resulted in the increase of worker-mothers. Unexpectedly, they are mostly absent from cinematic depictions of both work and the family sphere. An exceptional example of a film that promotes gender equality within a Yugoslav household, set in a past contemporary socialist Yugoslavia, is the formally and thematically mainstream Muškarci/Men (Milo Đukanović, 1963, Yugoslavia).

\section{Celluloid gender asymmetry in the family sphere and generational conflict}

The contrast between gender equality promulgated in socialism and the gender asymmetry in the family sphere is present in both everyday life of Yugoslavia (as the double-burden), as well as in the two films I discuss. The Beehive tackles the relativity of guilt via the public trial of a wife named Stojanka, exposed to shaming by a mob of villagers during the process. She allegedly betrayed her husband Nikola (Danilo 'Bata' Stojković) - an outlaw opposed to Ottoman rule and wanted for the murder of Halil bey (Bekim Fehmiu) - by revealing his whereabouts to the Ottoman occupiers. That resulted in Nikola's death by stoning inside a well where he was hiding. Supposedly, Stojanka arrives at such a difficult decision in order to prevent vengeful Halil bey's brother (also Bekim Fehmiu) from burning down her house and the people in it, including her newlywedded son Stojan (Dušan Golumbovski) and his bride Ljubica (Olivera Vučo). The Birch Tree is about fragile Janica, who perishes due to post-birth complications, the harshness of peasant life, lack of access to any proper medical care, and neglect by her mother-in-law and husband Marko Labudan (Velimir 'Bata' Živojinović).

In both films, motherhood is suppressed. Janica loses a new-born baby girl, who dies sometime after birth. Stojanka's son Stojan is killed by the Ottomans, while her relationship with her young daughter deteriorates because Stojanka offers herself to be raped by Halil bey in her place. She protects her from sexual assault with her own body but does not manage to spare the daughter from witnessing her own rape, which traumatises the girl. In The Birch Tree, the grim end of the main heroine is made known to the spectators early in the plot. Contrary to that, The Beehive is more open-ended, which leaves the spectators perplexed as to whether the heroine will be granted a pardon

[57] S.P. Ramet, In Tito's Time, [in:] Gender Politics in the Western Balkans: Women and society in Yugoslavia and the Yugoslav successor states, ed. S.P. Ramet, University Park 1999, p. 104.

[58] M. Morokvašić, op.cit., p. 136.

[59] D. Beganović, Changing fates: the role of the hero in Yugoslav Cinema in the early and late sixties, [in:] Retracing Images: Visual Culture After Yugoslavia, ed. D. Šuber, S. Karamanić, Leiden 2012, p. 135. [60] P. Favero, Blessed be the good soldier: cinema, media and the manufacturing of nationhood in post 9/11 Italy, "Archivio Antropologico Mediterraneo" 2011, 13 (1), p. 61. 
or severely punished for her purported transgression of social codes.

In order to establish a link between these cinematic depictions of the pre-socialist past in male-dominated societies and the seemingly unrelated real-life in the socialist present of the 1960 , I highlight that in both films, there is a generational conflict, manifest in the defiance of young girls towards their mothers regarding the choice of a romantic partner. In The Beehive, Ljubica's mother tries to convince her, immediately before and after her wedding, to leave the house she is marrying into, but in vain. Similarly, in The Birch Tree, both Janica's mother and brother chastise Janica for dancing three times with woodward Marko at a village festivity, despite the fact that he is a notorious womanizer, and that he had sued her father for cutting down an oak tree. It is important to note that in the reality of socialist Yugoslavia, the inviolable authority of parents over children started losing its grip due to the process of urbanisation.[61] This was because the patriarchal subjugation of women via men started significantly weakening, especially in regard to the economic sphere, since more women were becoming employed and educated.[62] This was also true in the legal sphere, where egalitarian inheritance, marriage and divorce rights were guaranteed to a married woman.[63] Urban living, and the migration of the work force from villages to cities, created conditions for greater independence and more freedom for children in a family, including the right to freely choose ones' future marriage partner.[64] This switch is indirectly reflected in the two analysed film representations.

[61] V. Gudac-Dodić, op.cit., p. 78.

[62] Ibidem.

[63] Ibidem.

[64] Ibidem.

[65] Ibidem, p. 91.

[66] Ibidem.

[67] Ibidem.

[68] Ibidem, p. 92.

[69] Ibidem, p. 96.

[70] Ibidem, pp. 34-43.

[71] Ibidem, p. 91.
However, the patriarchal way of thinking typical for agrarian environments, which lingered on from the pre-socialist era, was resistant to change.[65] The high influx of rural populations into the cities had the consequence that the traditional outlook on gender roles in the family also persisted in the urban environments to some extent. [66] While simultaneously being employed, women were also doing most of the household work, and often were solely responsible for the upbringing of their children.[67] Consequently, they were overburdened by their multiple roles. According to data from 1965, a woman worked, on average, somewhere between 60 and 70 hours per week (at work and at home), out of which between 20 and 30 hours were unpaid work (in her own home).[68] The socialist state tried to alleviate any contradictions that the societal role of the employed woman-mother brought, with increasing societal care for children, specifically by building public kindergartens, nurseries and day-care centres. [69] It is important to keep in mind that in Yugoslav socialism, many laws were ratified which were integral to gender equality, such as: women's right to vote and to be voted for; the right for equal pay for equal work; the right to keep one's maiden last name when marrying; the right to have full custody over children after divorce; the right to paid maternity leave before and after childbirth; the freedom of reproductive choice; the right to schooling and education; the free choice of profession and employment; the right to social services and health insurance.[70] Still, the enormous improvements that Yugoslav socialism brought, including economic independence and legal equality, were not enough to completely change the patriarchal mindsets of people and the image of women in the domain of family relations.[71]

\section{Bechdel test, 'reversed masquerade' and 'cryptomatriarchy'}

In order to fully comprehend how women are represented in the two studied films, it is important to explore the interpersonal relationships amongst themselves. The Beehive is one 
of the rare movies from Yugoslavian New Wave which, in my opinion, passes the Bechdel test (which investigates the presence of female characters in media). The Bechdel test originates from Alison Bechdel's comic Dykes to Watch Out For, where one of the characters declares that she only watches films if they meet three prerequisites.[72] Thus, it is undertaken by an examination as to whether: (1) there are at least two important female characters in a fiction film, (2) who talk to each other, (3) about something besides men.[73] In academic literature, it is also sometimes referred to as the Bechdel-Wallace test,[74] but nonetheless, its definition is the same. In addition, in some sources, a requirement for the test is that both women should be named.[75]

In The Beehive both names of the two most prominent female protagonists are known: Stojanka and Ljubica. The two women make a covenant between them, in the scene preceding the modest wedding ceremony of Ljubica and Stojanka's son Stojan, held in secrecy in Stojanka's house. Even though men are mentioned during this scene, it is done sporadically. Therefore, the main focus of their conversation is not on men, but on the mutual agreement between the two women on how to run and preserve the family, so the film passes the Bechdel test. Ljubica, being the reproductive female member in the family unit, takes Stojanka's place of the dominant matriarch. The shift in hierarchy is consensual. Stojanka utters and Ljubica repeats after her: 'God, give me happiness and longevity. And may

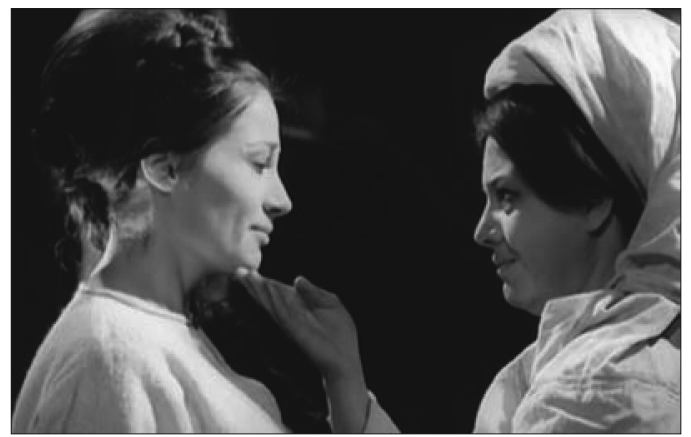

Il. 1. Caption from: Miodrag 'Mića' Popović, The Beehive, 1966
I become by right and on time the queen bee in this beehive. May I live in prosperity. And may my strength calm down with one husband. Amen.' The covenant is sealed when Stojanka touches Ljubica's chin (il. 1), after which Ljubica exclaims to Stojanka the word 'mother' with a lachrymose, trembling voice and hugs her. This signals not only Ljubica's acceptance of succeeding Stojanka as the queen bee of the family she is about to marry into, but an act of female bonding as well. However, there is an enmity between Stojanka and Ljubica's mother, though it does not affect Stojanka's relationship with Ljubica. On the contrary, Ljubica twice ignores her mother's urging to leave Stojanka's house and return home with her: the first time just before the modest wedding ceremony held in secrecy in the house, the second time when the Ottomans arrive in front of the house at the end of the wedding, in pursuit of Stojanka's outlaw husband. Ljubica's mother's opposition towards her daughter's marriage and her hostility to Stojanka only seem to fortify the embattled solidarity between Ljubica and Stojanka.

In The Birch Tree, female solidarity towards Janica is only expressed by Jaga (Hermina Pipinić), her in-law, who shows empathy for her when Janica is on her deathbed. The film passes

[72] T. Krijnen, S. Van Bauwel, Gender and Media: Representing, producing, consuming, communication and society, London 2015, pp. 19-20. [73] K.L. Hole, D. Jelača, E.A. Kaplan, P. Petro, Introduction: Decentering feminist film studies, [in:] The Routledge Companion to Cinema and Gender, ed. K.L. Hole, D. Jelača, E.A. Kaplan, P. Petro, New York 2017, p. 5.

[74] S. Chivers, "No place for sissies": gender, age, and disability in Hollywood, [in:] The Routledge Companion to Cinema and Gender, ed. K.L. Hole, D. Jelača, E.A. Kaplan, P. Petro, London, New York 2017, p. 74.

[75] M. Racic, Do this year's best picture Oscar Nominees Pass the Bechdel Test? Revisiting an imperfect but useful litmus test in light of \#MeToo, "The New Yorker" 2018, last modified 3/3/2018, $<$ https://www.newyorker.com/culture/culture-desk/do-this-years-best-picture-oscar-nominees-pass-the-bechdel-test $>$, accessed: 31.03.2018. 
the Bechdel test, for instance, because of a conversation between the duo, during which feverish Janica loses track of time due to the illness and asks Jaga how many days have passed since her new-born baby daughter Ljubica, who died ten days after birth, was buried.

Jaga stands out from other peasant woman not only because of her compassion for Janica, but with her orange pullover as well. Its warm colour correlates to her warm personality. In contrast, other peasant women are clad in dark clothing, ominous and malicious. The group gossips about Janica, in her presence, while she is on the sickbed, as if she were already dead. They say how she was always thin and weak, and express surprise while recounting how her husband Marko left a girl, who was fat, strong, and rich, for Janica. From this, it can be implied that in the countryside, where women were expected to do hard physical labour, slenderness was associated with sickness and corpulence with health. Although both films pass the Bechdel test, it does not necessarily mean that they depict women being kind to each other or expressing solidarity. Namely, there is a friction between Stojanka and Ljubica's mother. The most harrowing lack of solidarity that Janica experiences is from her mother-in-law.

Building on Riviere's concept of 'womanliness as a masquerade, [76] and in my view further influenced by Doane's 'theorization of femininity as masquerade',[77] Bogojević employs, within Yugoslav cinema, her own concept of the 'reversed masquerade', where female

[76] J. Riviere, Womanliness as a masquerade, [in:] Influential Papers from the 1920s, ed. R.D. Hinshelwood, London 2018, pp. 127-138, original edition 1929.

[77] M.A. Doane, Masquerade Reconsidered: Further Thoughts on the Female Spectator, "Discourse" 1988-1989, 11 (1), p. 47.

[78] M. Bogojević, op.cit., p. 259.

[79] Ibidem.

[80] Ibidem.

[81] A. Simić, op.cit., p. 28.

[82] Z. Lóránd, op.cit., p. 115.

[83] A. Simić, op.cit., p. 25.

[84] Ibidem, p. 14. characters, such as grandmothers and mothers, emphasise their masculine attributes and utilise them 'as a mask disguising and effacing their femininity'.[78] With the sense of womanliness obliterated, the androgynous older women, frequently clad in black, are far crueller than the male characters, as they fix both men and women with a sadistic voyeuristic gaze.[79] They reinforce patriarchal attitudes, initially adopted from their fathers and then spouses. [80]

Although intended for a different example and time period of Yugoslav cinema, Bogojevićs theory is applicable to my case study film The Birch Tree, because the aforementioned elderly women, grim and deprived of womanliness, show no empathy for beautiful and fragile Janica. Nevertheless, ageing is approached differently in The Beehive because mature and dignified Stojanka retains her femininity. She expresses no enmity towards her young and pretty daughter-in-law, but solidarity with her. While elderly women from The Birch Tree perpetuate patriarchy, Stojanka undermines and confronts it. In contrast, the worst mistreatment Janica encountered is from her insensitive mother-in-law, who pressures her - on a day she is so feverish that she could not even go to the graveyard, with her husband Marko to bury their new-born daughter - to take a cow to graze in the pouring rain. This contributes to Janica's premature death.

A family constellation in socialist Yugoslav society was labelled by Simić as 'cryptomatriarchy',[81] in some of its traditional incarnations. However, references to matriarchy should not create a misleading impression of 'a denial of women's subordination by implying that it is women who are in power in fact.'[82] Actually, there is a discrepancy between the coexistent unexpected power of elderly women and the machismo of a patriarchy marked with patrilineality.[83] The power of women was obfuscated, due to the seemingly male dominance over the household members and society in general, which was 'more a public than a private fact.' [84] Women attained 'this power not by virtue of being wives, but as the result of becoming mothers, 
and, eventually, grandmothers'. [85] Not only in rural, but even in urban environments where they predominantly worked, women ran the family domain, while simultaneously 'exerting a certain influence on their sons even outside the context of family life.'[86] The revered and authoritative position of mothers increased gradually with time through their sons as proxies.[87]

In contrast to the influential position of mothers and grandmothers, daughters-in-law were regarded as outsiders upon entering the husband's extensive family and were utterly powerless until the birth of their own male children, who would perpetuate the family name. [88] Due to an initially subordinated position, a daughter-in-law's prospect of marital union was reliant on a good relationship with her dominant mother-in-law, because of the 'powerful influence of mothers in the marital affairs of their sons.'[89]

In line with Simić's thoughts on 'cryptomatriarchy' in real life, in The Birch Tree, 'the real threat to a woman's position in the family stems, not so much from her husband as from her mother-in-law, against whom a daughterin-law's principal weapon is the status and pride that results from grandparenthood'.[90] By failing to provide a healthy male heir, Janica's already inferior status as a newcomer worsens further, whereas Ljubica's implicit pregnancy in The Beehive contributes to elevating her status as a matriarch, as a queen-bee. The role reversal between Stojanka and Ljubica is obvious in the denouement of the film when Stojanka, the former symbolical queen-bee, is shown leaning her head on Ljubica's shoulder, as if passing on to her the legacy of the role of the new queenbee. Both Popović and Babaja are critical of the patriarchy, while Babaja places the forces of patriarchy not only in male characters, but in female as well; for instance, Janica's motherin-law and other elderly women. This relates back to the point that women's relations, in the studied films as well as in life, are not uniquely ones of solidarity and resistance. Nevertheless, this might be problematic if understood without taking into consideration the context that women, socialised as such, perpetuate the patriarchal stances accrued from their fathers and spouses.

\section{Victimization}

According to Kaplan, among the patriarchal mechanisms to control female discourse and desire in Hollywood cinema are victimization, self-righteous murder, rape, and fetishizing. [91] In the victim pattern, the female protagonist suffers and often perishes through illness or impoverishment. [92] ' $\mathrm{T}$ ] he figures women are asked to identify with are usually victims.'[93] Those victimized and powerless female characters reinforce the sense of worthlessness among female spectators.[94]

Similarly, Haskell[95] points out that in Hollywood women's films, ordinary heroines were portrayed as victims through the myths of self-effacement and martyrdom, which were also buttressed by the mass media. The underlying motive of those representations is to maintain patriarchy by influencing women to come to terms with the position they are stuck in, and hence to discourage them from questioning it.[96]

Examples of the victimhood pattern can be found also outside the Hollywood cinema. The case study film The Birch Tree illustrates how director Babaja reinforced gender norms permeated with the patriarchal subjection of

[85] Ibidem, p. 14.

[86] Ibidem, p. 27.

[87] Ibidem, p. 24.

[88] Ibidem, p. 18.

[89] Ibidem, p. 23.

[90] Ibidem, p. 22.

[91] E.A. Kaplan, Motherhood and Representation: The mother in popular culture and melodrama,

London 1992, p. 7.

[92] Ibidem, p. 6.

[93] Ibidem, p. 49.

[94] Ibidem, p. 104.

[95] M. Haskell, From Reverence to Rape: The treatment of women in the movies, 2nd ed., Chicago 1987 , pp. 160-161.

[96] Ibidem. 
women by following the victimisation pattern, if Kaplan's, [97] and Haskell's [98] theories are applied to Yugoslav New Film. The film is reminiscent of melodramas, which were, according to Fischer, [99] in the most cases directed by men, and foregrounded a female heroine who faces a predicament in her domestic life revolving around the motherhood and marriage. Doane notes that in that genre, heroines have been disconnected from desire.[100] 'The dominance of the bed in the mise-en-scene of these films is the explicit mark of the displacement/replacement of sexuality by illness.'[101] Likewise, The Birch Tree's main heroine Janica does not have an active sexuality. On the contrary, Janica's love for her husband Marko seems almost platonic and not corporeal. Regardless, Janica's choice of a life partner of a man whom she was warned about, a womanizer, leads her to a grim destiny, as if she takes his sins upon her. After the new-born baby she gave birth to died, Janica also falls ill and perishes, probably as a consequence of an unsanitary countryside childbirth without medical assistance. As Chakravarty notes, women appear inseparable from their bodies.[102]

[97] E.A. Kaplan, Women and Film: Both Sides of the Camera, London 2000.

[98] M. Haskel, op.cit.

[99] L. Fischer, Feminist forms of address: Mai Zetterling's loving couples, [in:] The Routledge Companion to Cinema and Gender, ed. K.L. Hole, D. Jelača, E.A. Kaplan, P, Petro, New York 2017, p. 36 .

[100] Ibidem.

[101] M.A. Doane, The "woman's film": possession and address, [in:] Re-Vision: Essays in Feminist Film Criticism, ed. M.A. Doane, P. Mellencamp,

L. Williams, Los Angeles 1984, p. 79.

[102] S. Chakravarty, Gender in transit: framing the cinema of migration, [in:] The Routledge Companion to Cinema and Gender, ed. K.L. Hole, D. Jelača, E.A. Kaplan, P. Petro, London, New York 2017, p. 58.

[103] V. Gudac-Dodić, op.cit., p. 108.

[104] Ibidem, p. 124.

[105] Ibidem, p. 106.

[106] Ibidem, p. 108.

[107] E.A. Kaplan, Women and Film...
Following the Second World War, in Yugoslavian villages, births continued to take place under inadequate conditions, since customs and beliefs were given preference by the countryside folks to proper medical assistance. [103] After liberation, and in the decades that followed, many institutions focused on the protection of women, pregnant women and mothers.[104] Despite all the efforts of the socialist state and the women's organisation AFW (Antifašistički front žena/ Antifascist Front of Women) to provide healthcare and enlighten the people health-wise, for the majority of women, in many rural parts of the country, bad hygienic habits and superstitions persisted for a long time.[105] In Yugoslavia, of all the babies born in 1961, 46,7\% were delivered without professional help.[106] The reluctance of individuals in more rural villages to seek proper medical aid, not only during childbirth but also in regard to any type of illness, is echoed in the film The Birch Tree.

When Janica is on her deathbed, Jaga goes out of the house and calls Marko to come inside because Janica wants to see him for the last time, but he is busy preparing the decoration of the flagpole. He has been asked to be a flag-bearer at a wedding, which is a traditional custom. For him, this element of tradition is apparently more important than saying goodbye to his dying wife. His response to Jaga is that he will go see Janica when he finishes adorning the flagpole. It is difficult to comprehend why he even accepted the joyful role in the oncoming wedding festivity in the first place, especially knowing he might be in mourning at any moment. He also prioritizes insignificant preparations instead of Janica, so she passes away without her dying wish being fulfilled: to see the man she loves. Therefore, Janica's fate fits the above-mentioned victimization pattern.[107] After she is buried, Marko indulges in hedonism at the wedding celebration, but eventually goes through the moment of catharsis where he repents and humbles himself in front of the white birch tree, which symbolizes Janica.

Thus, the woman is victimized with pathos. In this film, the underlying androcentric ide- 
ology of the patriarchal society is that women should tolerate husbands who neglect them, because if they do so, their soul will go to heaven. They will be rewarded in the afterlife for the hardships they have suffered. Despite the fact that Babaja's film is critical of patriarchy by the very selection of theme and giving prominence to a woman, it still reinforces gender inequality by the usage of stereotyped representation of a saint-like, passive and neglected female character who acquiesces to her suffering. To borrow Kaplan's thoughts on American melodrama, a film can simultaneously have elements resisting dominant patriarchal gender ideology and closure that buttresses it.[108] Consequentially, it appears that the narrative normalizes female suffering, reinforces the male-dominated order and controls women by implanting the idea of posthumous reward or sanctified remembrance after underappreciated existence.

In contrast, The Beehive portrays a woman who refuses to be victimised. When Stojanka is raped, she is not overtaken by the rapist Halil bey, but instead she deliberately offers herself in order to protect her daughter from impending rape. However, her sacrifice is not appreciated by her husband Nikola, nor by her daughter. In fact, she is exposed to victim-blaming, because Nikola calls Stojanka a 'Turkish whore', as if it was her fault for being sexually assaulted. Although Nikola kills the rapist, he does not arrive in time to prevent the rape, but only interrupts it. Building on Žižek's theory of the impotence of the gaze when a male figure of authority forcibly witnesses the rape of a family member, which activates 'the vicious cycle of guilt',[109] Brinkema[110] points out the utter powerlessness of a samurai husband, eye-witness to the rape of his wife in Rashomon (Akira Kurosawa, 1950). Correspondingly, Nikola projects his own humiliation onto Stojanka due to witnessing her rape (implied, not shown), because the harsh words he utters are most likely his own sense of guilt reshaped into blame. Not only does Stojanka's relationship with her husband deteriorate due to her rape, but that with her traumatized daughter does as well. They both ironically ask Stojanka on separate occasions if it is possible to breathe under the hay, alluding to her rape, when she pulled a stick that was holding some hay above her and the rapist to make it fall on them, in order to prevent her shocked daughter from watching. The patriarchy not only blames Stojanka for being raped, but later for Nikola's death when she finds herself exposed to shaming at the public trial. Ultimately, Stojanka is, in Haskell's words on Hollywood cinema, 'the woman who begins as a victim of discriminatory circumstances and rises, through pain, obsession, or defiance, to become mistress of her fate. [111] Even when the odds are against Stojanka, she is not a passive object, but an active, defiant subject who stands behind her decisions.

A certain empathy may be discerned in Popović's stance towards women through some details of the plot. During the incident when the Ottomans trap the subjugated village people in the courtyard of the caravansary and beat them in order to give away the outlaws' hiding place, they also suspend an orthodox priest by his neck with a noose, and leave him in a position where he barely touches the ground with his feet. When Stojanka's young daughter is dragged by the Ottomans to be raped, Kahriman (Rade Marković), as the mouthpiece for the director, says to the hung priest: 'Oh my priest, after all it is more difficult for a woman in a white gown than for you in a black one. However, any exposure of female characters to sexual violence, even if the director has a critical stance towards it and it is implied instead of shown like in The Beehive, might be still interpreted as problematic because it increases the amount of represent-

[108] Eadem, Motherhood and Representation..., pp. 172-173.

[109] S. Žižek, The Metastases of Enjoyment: Six Essays on Woman and Causality, London 1994, p. 74.

[110] E. Brinkema, The Fault Lines of Vision: Rashomon and The Man Who Left His Will on Film, [in:] Rape in Art Cinema, ed. D. Russel, New York 2010, p. 33 .

[111] M. Haskell, op.cit., p. 161. 
ed violence towards women in public discourse. Thus, both Babaja and Popović victimised their characters.

\section{The iconography of women and the feminine}

Another approach to investigating the representation of female characters is looking into their iconography, which can be used to diverse effects, such as to stereotype, disempower or empower. For example, patriarchy can be expressed through stereotypical visual iconography of female protagonists, such as mother, child, grandmother and good wife.[112] A good wife is blonde,[113] as Janica from The Birch Tree is, whereas Stojanka from The Beehive follows the pattern of a self-sacrificing mother to some extent. During the time of silent cinema, because the spectators struggled to grasp the plot from the speechless images, the producers simplified matters by introducing fixed character iconography.[114] Thus, audiences were promptly provided with information about characters of both genders, because their looks, conduct and traits were standardized, which resulted in stereotyp-

[112] J. Lesage, The political aesthetics of the feminist documentary film, "Quarterly Review of Film Studies" 1978, 3 (4), p. 517.

[113] Ibidem.

[114] A.L. Panofsky, From epistemology to the Avant-garde: Marcel Duchamp and the sociology of knowledge in resonance, „Sage Journals” 2003, vol. $20, \mathrm{nr} 1, \mathrm{p} .77$.

[115] C. Johnston, Women's cinema as counter-cinema, [in:] Feminism and Film, ed.

A.E. Kaplan, New York 20oo, p. 23.

[116] Ibidem, p. 25.

[117] J. Ryland, Iconography, [in:] The Women's

Companion to International Film, ed. A. Kuhn,

S. Radstone, Berkeley 1990, p. 212.

[118] W.S. Heckscher, Art and Literature: studies in relationship, Baden-Baden 1994, p. 146.

[119] M. Vaquero, A recurrent theme of the Spanish medieval epic: complaints and laments by noble women, [in:] Epic and History, ed. D. Konstan, K.A. Raaflaub, Chichester 2010, p. 318. [120] A.N. Didron, Christian Iconography; or, the History of Christian art in the Middle Ages, trans. E.J. Millington, London 1851, p. 466. ing. Johnston[115] points out that cinema quickly found a diversity of expression for portrayal of male characters, whilst the representation of female characters remained limited and stereotypical, undergoing only slight modifications, in comparison with the images of women from the silent cinema Panofsky described. Woman is portrayed as unchanging and infinite; thus, she is inhibited as a social and sexual being. [116]

In both films, an important female protagonist is, at a certain point, iconographically associated with an animal, insect or a plant. Iconography as a concept detects and categorizes the significant patterns, which can be conducted by numerous ways of analysis, such as a holistic perspective in terms of the general visual style of the film, or a specific one, in regards to particular symbols that are embedded in the film,[117] the latter being the focus of interest in this article. While in The Beehive, Stojanka and Ljubica personify a queen bee, the heroine from The Birch Tree, Janica, is iconographically linked to a slender birch tree, and also, at the moment of her demise, with a white dove. In Christian iconography, the white dove symbolizes a soul or the life spirit of the faithful aspiring towards heaven.[118] Also, some female Christian saints, for instance, Saint Eulalia of Mérida, are portrayed at the moment of their demise with a white dove, signifying the soul, flying out of their body to heaven.[119] The very moment when Janica dies, a white dove flies out of the house towards the sky, which an odd, religious, male villager Joža (Fabijan Šovagović), nicknamed 'the Holy', sees, but the husband Marko does not. The white colour of the bird in Christian art implies that the spirit is good. [120] When the Catholic priest arrives too late to administer the last rites, because Janica has already died, a tearful Joža humbly declares, on his knees, that the white dove he saw flying out of the roof of Marko's house at the moment of Janica's demise was her soul, as pure as the white dove, but the priest dismisses the idea.

Furthermore, trees are used twice as an iconographic analogy for Janica's dissimilarity to other country girls. It is said that she resem- 
bles a slim birch tree, whereas they are equated to sturdy beech trees. Birch has white bark and is thin and tall, just like the slender Janica, who is always dressed in light colours - mostly white or light beige - both in life and death. She wears a light-toned, beige sweater with a white apron, over a pale-coloured skirt when she does daily chores, such as attending grazing cows; she stands out in white during a village dance festivity while the other girls wear colourful orange embroideries; her head is also seen festooned with a plain white scarf (il. 2) that underlines her exquisite beauty and virtue due to its resemblance to a nun[121] (in a scene after the festivity, when her mother and brother scolded her for dancing with Marko); she was adorned in white when she was getting married; and she was also in white when her deceased body was exposed in an open coffin. In the Western Christian Church, white is a symbol of purity and innocence.[122]

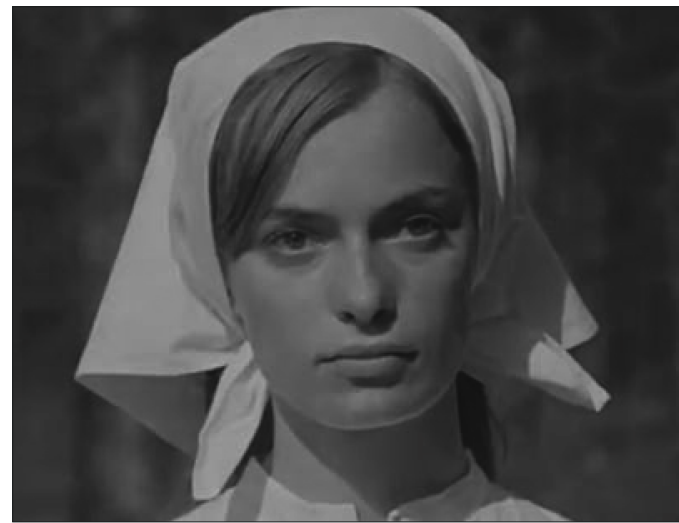

Il. 2. Caption from: Ante Babaja, The Birch Tree, 1967

The film makes a full circle. It begins with a scene where the ailing Janica appears in light coloured, whitish clothing, with a single whitebarked birch tree; thus, the director draws a parallel between the two by underlining their symbolic relation in as many as eight shots in that scene. When a feverish Janica collapses, while cows are grazing in the pouring rain, pious Joža, who was nearby, carries her in his arms to her husband's house. Throughout the film, characterised by complex plotting, the scenes of Janica's illness, looming death and funeral, are interspersed with retrospective scenes of Janica's life. In one retrospective scene, Janica, still unmarried, speaks to Joža, while sitting next to the birch tree to which she is iconographically linked (il. 3). Platonically in love with her, Joža is carving an angel out of a piece of wood with, as he states, resemblance to Janica in order to capture and preserve the great, fleeting beauty given to her by God. He advises her never to marry anyone, but instead become a nun. Janica responds that she would go for Marko right away if he wanted her, in a display of utmost female submissiveness. Consequently, the choice of earthly over heavenly seals Janica's fate. After her death, Joža places the angel he carved on her grave, which echoes Grant's assertion that 'religious icons are always already infused with symbolic meaning.'[123] Thus, director Babaja elevated Janica to the status of a symbol - an Angel - just like the pious Joža symbolises the Apocalypse, a recurring old woman perpetually spinning wool represents Death and Janica's husband Marko stands in for a Demon.[124]

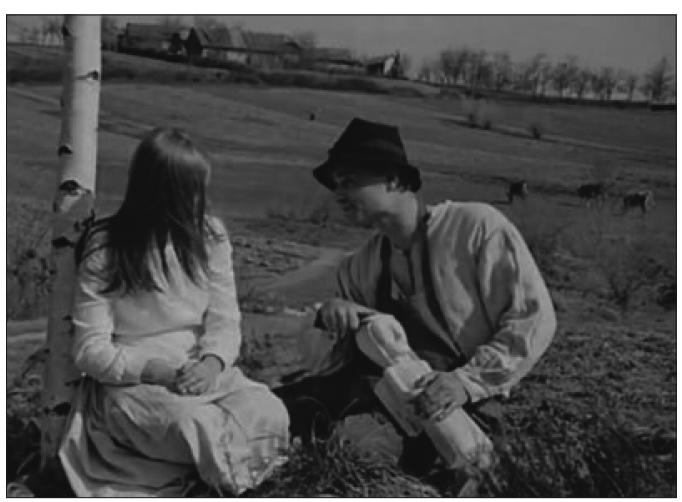

Il. 3. Caption from: Ante Babaja, The Birch Tree, 1967

The film ends with a scene in which the newly-widowed Marko, after a night of brawling,

[121] As kindly pointed to me by Dr Alex Forbes. [122] J. Gage, Color and Meaning: Art, Science, and Symbolism, Berkeley 1999, p. 70.

[123] B.K. Grant, Film Genre: From Iconography to Ideology, London 2007, p. 12.

[124] P. Krelja, Breza - film za sva vremena..., p. 15. 
excessive drinking and womanising, at first in a fit of rage, wants to tear down the very same above-mentioned birch tree with an axe. He then does completely the opposite. Ashamed and humbled, he kneels down next to the birch tree, and while hugging it, shrieks 'Janica' in remembrance of his departed wife, whom he could have treated better while she was alive. In addition, the title of the film The Birch Tree emphasises this relation between Janica and the birch tree, illustrating to the spectators that the birch tree stands for Janica. She, therefore, is seen to have fulfilled the path of victimization, from neglected and self-effacing wife during life, to posthumously appreciated and sanctified, as if the moral of the story was that women should endure the hardships of life because there is a reward in the afterlife.

As in The Birch Tree, in The Beehive there is also an iconographic motif that recurs throughout, but in this case, it is the bee. Its iconography is revealed in the opening shot of the film, which shows a swarm of bees on a honeycomb (il. 4). The shot is underscored with humming music composed by Zoran Hristić, which sometimes evokes the buzzing sounds produced by a swarm of bees. The opening credits roll over the image of bees. Eventually, once the credits are finished, the shot dissolves into a medium close-up of Stojanka, which then dollies in to her close-up (il. 5). She appears as if she is looking at the camera, thereby breaking the fourth wall. The brazen gaze that Stojanka returns to the camera-cum-spectators, her proud posture underlined by the slight low angle framing and the above-mentioned editing technique of the dissolve, which juxtaposed Stojanka with the shot of bees, all imply she is the queen of the beehive, the matriarch.

The iconographic leitmotif, bees, appear again in a line from the film, spoken by Kahriman, nicknamed Turk: 'A woman is, in any case, a man's doom, like a bee for a drone: first she overwhelms him, then crushes him and at length stays to live with the posterity. This zoomorphism (that is,

[125] A.G. Woodside, Case Study Research: Core Skills in Using 15 Genres, Bingley 2017, p. 144. the inclination to perceive the human behaviour through the lens of the behaviour of animals),[125] originates from Kahriman, who is the voice of the reason in the film. In my opinion, he is the voice of director Popović. Given that Kahriman has beehives, much of his wisdom springs from observations of the life of bees.

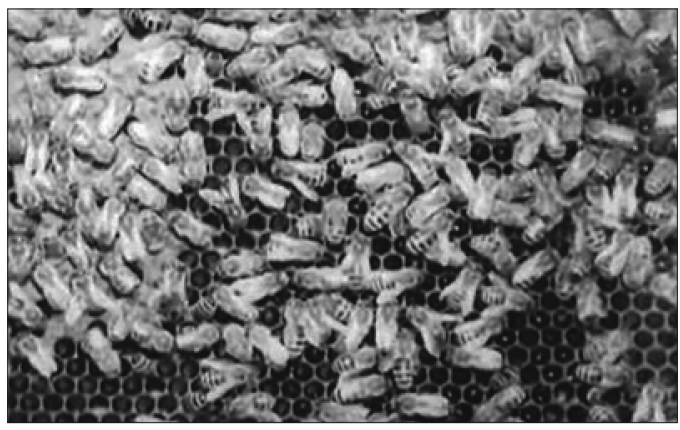

Il. 4. Caption from: Miodrag 'Mića' Popović, The Beehive, 1966

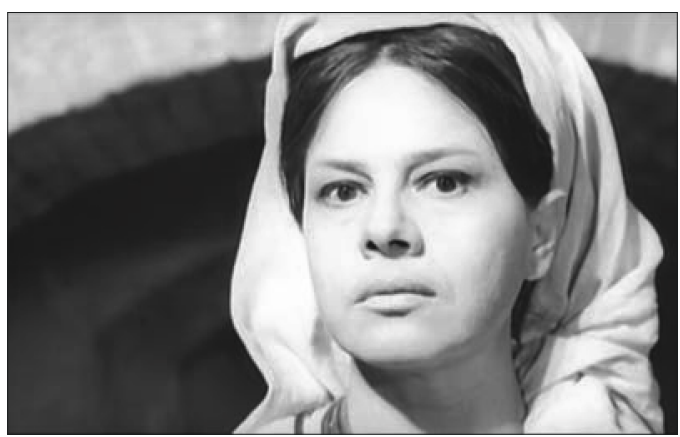

Il. 5. Caption from: Miodrag 'Mića' Popović,

The Beehive, 1966

A judge orders Kahriman to testify at Stojanka's trial, held in the caravansary's courtyard after the defeat of the Ottomans, and resembling Rashomon, due to the multiple perspectives shown in retrospective sequences (for example, of Ljubica's mother, a priest and Kahriman). Kahriman's testimony is not only aimed at his diegetic audience of villagers, present at the public hearing and resembling the chorus in a Greek drama, but also at the film viewer, because he occasionally looks directly at the camera. At first, it appears as if Kahriman-cum-director is judgmental of Sto- 
janka's potential responsibility in the death of her husband. However, Kahriman eventually takes Stojanka's side, as if assuming the role of her spokesperson in light of her almost impenetrable silence. To borrow Blackwell's words on a silent woman from The Seventh Seal/Det Sjunde inseglet (Ingmar Bergman, 1956) ' $\mathrm{t}] \mathrm{he}$ silence that defines her character lends her authority, for silence articulates disillusionment with the patriarchy and insight into the corruption of language inherent in it.'[126] Owing to Kahriman, in the course of the trial, although mostly stubbornly silent but powerful regardless, Stojanka is gradually given an opportunity to be understood, instead of condemned for her decisions.

In one of Kahriman's testimonial declamations, occasionally directed at the camera, director Popović modernistically intertwines past and present. Kahriman is visually placed in the past, witnessing an incident at the very same location - the caravansary's courtyard - where the present-day hearing takes place. Once he remains alone, his oration starts, as if on cue. However, he is sonically situated in the present time of the film, addressing his - in this instance - invisible but implied audience, from Stojanka's trial in the present. Kahriman iconographically links men and drones, by verbally collocating them: 'Warriors, heroes, outlaws, men, drones, the top brass, you know nothing except to fight and protect your honour, and that is worth nothing. Thus, he implicitly criticises patriarchy. Further on in his lengthy speech, while directly looking at the camera he addresses Stojanka and her daughter-in-law, Ljubica, whom he iconographically relates to a queen-bee:

When the time comes that the young queen bee replaces the old one, the two of them agree on something important. What is the message that the old queen bee passes on the young one and pledges her to do? What is it that the young queen bee learns and that is the most important until eternity? Stojanka? Ljubica? [127]

In the following retrospective sequence, it is implied that Stojanka tried to avert the Otto- mans from setting her house on fire with household members inside, in order buy time for the newlyweds to extend the lineage of the family by procreation, in an ultimately futile attempt to save her son. The mission to perpetuate the symbolical beehive is what she taught Ljubica, upon passing on to her the legacy of the role of the queen-bee. Theory on The Seventh Seal is applicable in this instance, stating that the film affirms Western culture's very problematic equation between the female and emotion, nature, and family'.[128]

In another scene earlier in the film, Kahriman says 'fertile as Ljubica' and points a finger at her, whereupon she faints, as if taking a cue from him. This implies that she is pregnant. While one man pours water over her and helps her, together with her mother, to stand up, Kahriman states:

When a young queen bee grows strong and flies upwards, befuddled drones follow her. The queen bee flies higher and higher. The weaker drones fall behind, one by one. At length, the strongest drone catches up with the queen bee. She gives herself to him. They both have a nice time. Afterwards he falls dead, and she returns to command in the beehive. By right and on time.

During this speech, Ljubica is present in the most of the shots: either in the foreground or background of the compositions that include Kahriman, or in a shot excluding him, but underscored with Kahriman's voice-over. Thus, the directorial intent was to iconographically link Ljubica with the young queen-bee. Although director Popović reinforces the essentialist stereotype of women as related to nature and reproduction, he posits the family hierarchy as matriarchal, empowering female characters through the iconography of bees.

[126] M.J. Blackwell, The Seventh Seal (1956): Cinematic form and cultural criticism, [in:] Film Analysis: A Norton Reader, ed. J. Geiger, R.L. Rutsky, New York 2005, p. 543.

[127] All the translations from Serbo-Croatian are mine.

[128] M.J. Blackwell, op.cit., p. 540. 


\section{Superstition}

In contrast to the empowerment of two female characters by associating them with queen bees, a male character in The Beehive is disempowered by being linked with a lifeless drone, through the interplay between iconography and supernatural beliefs. Actually, in both films, there are supporting female characters who resort to magic in order to heal or to harness power; thus, to borrow Jovanović's words on sorceresses in the Yugoslav Classical cinema, '[e]mbodying the pre-modern ignorance'.[129] In a scene taking place on the wedding night, Ljubica's mother gives bride-to-be Ljubica a small, lucky charm bundle, made of cloth with a honeycomb and a dead drone inside. The magic superstition is supposed to ensure Ljubica a special place in her new home. If she throws the witchcraft bundle in the well, all of the household members will obey her when they drink the enchanted water.

The bundle is found by Stojanka's husband Nikola inside the well, his hiding place, a few moments before he will be stoned to death by his enemies, the Ottomans. The charm brings him bad luck and becomes a sinister omen of his demise. This retrospective sequence toward the beginning of the film stages Kahriman's recounting of the events from a third-person omniscient perspective, since it would have been impossible for Kahriman to see what is happening with Nikola and the dead drone deep inside the well. In the preceding scene, before Nikola discovers the charm, his wife Stojanka makes a step forward towards the well. Her motives for doing so remain ambiguous, but in the context of the sequence, her actions appear to indicate that she is presented with the dilemma of whether or not to divulge Nikola's hiding place to the Ottomans.

In the scene that follows Nikola's bundle discovery, when according to Kahriman's version of the event, Stojanka reveals that Nikola is in the well, the camera zooms into her face from medium close-up towards full close-up,

[129] N. Jovanović, op.cit., p. 149. emphasizing the gravity of her position. However, Ljubica's testimony in the denouement of the film, shown in retrospective from the neutral, third-person perspective, eventually sheds new light on the event and to some extent contradicts Kahriman's recollection. It is, therefore, reminiscent of Rashomon's multiple perspectives during a trial. Ljubica - who was inside of the house with some wedding guests and her newlywed husband, Stojanka's son gives an account of the incident, stating that she asked Stojanka to stall the Ottomans. As the story unfolds, it becomes clear that Stojanka did not tell the Ottomans where Nikola was hiding, but on the contrary, Nikola fired a gunshot at her when she leaned above the well, thinking wrongly that she had betrayed him. Thus, he reveals his hiding place himself. Nevertheless, it remains ambiguous as to why Stojanka went to the well in the first place. Was it just to buy time from the Ottomans or contemplate whether she must commit treachery for the purpose of trying to futilely save her foolhardy son, by enabling him and her daughter-in-law Ljubica to consummate their marriage in order to protect the family line from perishing? Furthermore, it is unclear whether Stojanka knew where Nikola was hiding at all, because she was inside the house when he hid. Once he gives away his hiding place to the Ottomans by shooting at Stojanka, they start throwing rocks at him. Director Popović underscores Nikola's demise by creating an audio-visual connection between him and Stojanka. Back in the house, every time Stojanka hears the sound of a rock landing inside of the well, and potentially killing Nikola, she hits her head on a wall, corporeally expressing her grief.

The deeper meaning of Nicola's death is grasped through iconography. Stoned to death by Ottomans in the well, iconographically speaking, Nikola becomes the dead drone. The link between the two is visually amplified in Kahriman's aforementioned recollection, with a tilt up from a detail of a dead drone on top of a honeycomb, held by Nikola's hand, onto a big close-up of Nikola's face. Sorcery with the dead 
drone, therefore, does not cause his demise, but foreshadows it.

Similarly, in The Birch Tree, female characters resort to the supernatural. When Janica's fatherin-law Tomo (Stjepan Lektorić) suggests his wife call a doctor in order to examine the gravely-ill Janica, she rejects the idea. Instead, she decides to invite an old woman, called Ježovićka, who performs magic healing rituals by removing curses, hexes and spells. Janica's mother-in-law further states that if Ježovićka cannot help Janica, not even God can. This reflects a rural way of thinking imbued with superstition, prejudices, and, as Rožić would have it, 'a blend of Christianity with almost magical concept of life.'[130] The conversation takes place while tending two cows. It ends with a conciliatory statement by Tomo: 'Do as you wish, those are your female matters'. In line with Simić's view on phenomenon of 'cryptomatriarchy' in Yugoslav society, 'the authoritative and influential positions occupied by older women appear anomalous in light of a social character stressing patrilineality, patrilocality, and male dominance.'[131]

The arrival of the village sorceress Ježovićka across a meadow is observed and announced by a little boy. Also, it is underscored with the music of composer Anđelko Klobučar, which introduces the notion that something peculiar is about to take place. '[T]he scene of "curing" ill Janica with paganist ritual may be understood as direct announcement of death.'[132] Once inside the house, Ježovićka concludes that someone cast a spell on Janica. Ježovićka's and faces of other women present in this scene, with the exception of Janica, are enveloped in dark scarves, which gives the impression of a funeral wake.[133] Also, the female characters are clad in black, murky blue and dark green, cold-coloured clothing, except for the positive female character Jaga, who wears a warm-coloured terracotta orange waistcoat pullover, and Jani$\mathrm{ca}$, who is covered with an orange blanket and wearing a white shirt. Orange, red and yellow are regarded as warm colours, because an image abundant with them will provoke an optimistic feeling in the viewer, whilst green, blue, and violet are perceived as cold colours and will invoke an opposite, pessimistic emotion.[134] Predominantly cold colours are in accordance with the sad plot points - Janica's illness and forthcoming death - eliciting a sombre mood in the viewer. The colour concept employed in sad scenes is that cold colours are in the majority, whilst warm terracotta appears in traces, often as their striking visual counterpoint.

Commencing the supernatural ritual, Ježovićka deposits hot coals into a clay bowl with water and hovers with a knife above it, making the sign of a cross. This is underscored with Ježovićka's ominous chanting and music by Klobučar. In the following magic ritual, she places on Janica's belly what appear to be two trimmed horns with clipped tips and blows into them. Then, she puts squirming leeches on Janica. The menacing atmosphere is also amplified throughout the scene with the usage of expressive close-ups. For instance, the cold-hearted mother-in-law is opposed to a dead chicken hanging upside down on a rope, foreshadowing the outcome of her cruel treatment of Janica. In addition, an old woman who recurs through the film spinning wool, reminiscent of one of the Greek Moirai (the Fates), is shown engulfed in gloomy fumes of burning coal. Beside the old face of Ježovićka, portrayed in close-up in the foreground, is juxtaposed a crucifix, the symbol of Christian iconography that hangs on the wall in the background, thus signifying a mixture of Christianity with superstition. The supernatural curing session ends on a sour note with Janica fainting.

In a further sequence of a supernatural ritual, also set during Janica's life, the ordinary peasant women try to heal her by making her look at her reflection in a mirror (il. 6).

[130] R. Rožić, Život je žilav - Janica je živa?!, "Hrvatski filmski ljetopis" 2010, 16 (62), p. 22. Own translation.

[131] A. Simić, op.cit., pp. 13-14.

[132] P. Krelja Breza - film za sva vremena..., op.cit., p. 13. Own translation.

[133] Ibidem, p. 15.

[134] J. Cox, Digital Nature Photography, New York 2003, p. 43. 


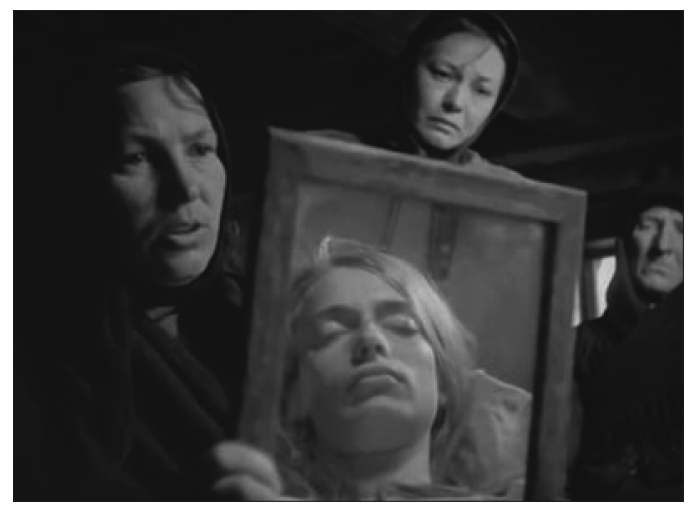

Il. 6. Caption from: Ante Babaja, The Birch Tree, 1967

Superstition looms after Janica's death as well, when one of the peasant women covers the mirror with a black headscarf. As Perić notes, it was believed that the deceased would come back home if they saw their own reflection in the mirror.[135] Also, one female hand shown in a detail shot stops the pendulum of the clock. Subsequently, the peasant women throw water out of the old wooden trough bowls behind the departing funeral procession. The custom is also intended to prevent the deceased person from returning.[136]

In both of the films studied, female characters who perform sorcery personify the poverty, ignorance, lack of education and backwardness of the pre-socialist countryside. These are portrayed in The Birch Tree in monarchist Yugoslavia and in The Beehive under oppression by the Ottoman occupiers. Witchcraft is exclusively associated with the feminine. In The Beehive, it serves as a bad, foreboding omen, foreshadowing Marko's death, whereas in The Birch Tree, it contributes to the demise of the heroine, because she is placed in the hands of an incompetent, superannuated local female folk healer, instead of a competent doctor.

[135] T. Perić, Tradicijska glazba i običaji Sjeverozapadne Hrvatske, Bachelor's Degree Bachelor's thesis, Odsjek za učiteljske studije, Sveučilište u Zagrebu - Učiteljski fakultet 2016, p. 58.

[136] Z. Rajković, Narodni običaji okolice Donje Stubice, "Narodna umjetnost" 1974, 10 (1), p. 193.
The films criticise patriarchy, while at the same time, by inclusion of the witchcraft performed by female characters, implicitly blame women for predicaments that occur and their place in patriarchy, especially in The Birch Tree. The portrayal of Janica's mother-in-law suggests that she bears the responsibility for bringing the village sorceress instead of taking Janica to a doctor, which ends fatally, whereas Marko as a husband should have been culpable. In The Beehive, the indictment of female guilt is proclaimed by a woman. Stojanka's young, traumatised daughter accuses Ljubica and Ljubica's mother of being indirectly accountable for her father's death, due to their charm with a dead drone, although the Ottomans are the ones who actually killed him by stoning him. Simultaneous oppression of female characters by the patriarchy, while some of them inadvertently act as its proponents, demonstrates the ambivalent stance of the directors on women. They are concurrently critical of women's treatment by patriarchy, while chiding them for how they mistreat each other, mainly as seen in The Birch Tree. On the other hand, the directors tackle female solidarity, of which The Beehive is a strong example.

\section{Conclusion}

Yugoslav socialist society fostered female emancipation due to its progressive legislation from 1946 onwards. This gave women equal rights with regards to the workplace, education, marriage, divorce, inheritance, one-year fully paid maternity leave, and freedom of choice, while simultaneously the remnants of patriarchal mentality lingered within the family sphere. Although set in pre-socialist times, the analysed films implicitly criticise the vestiges of gender inequality in the family domain of their socialist present. Keeping in mind that Yugoslav New Film was auteur cinema, I argued that Babaja and Popović, by deliberately regressing into the past instead of choosing contemporary themes, fully scrutinise patriarchy in the family domain, without catering to the official gender equality discourse. Although the two analysed 
films are far from feminist films, due to using regressive stances towards the women depicted, still, they not only address gender troubles in bygone pre-war times, but also point to their present-day, post-war social problems. However, besides criticising the patriarchy, Babaja, and to a smaller extent, Popović, also put the blame on women as executors of the patriarchy, due to expressing enmity towards other women. While Popović stresses camaraderie amongst women more than friction, Babaja emphasises rivalry between women more than solidarity and also vindicates Marko by showing him repent for neglecting Janica, instead of condemning him for her death. Although hostility between women is unfortunately part of real-life societies, without setting it in the proper context that women are socialised to be enemies by their male family members, female family members who perpetuate patriarchy, and society in general, the directors take an ambiguous stance towards male-oriented ideology.

Furthermore, this research assessed the meanings behind the iconography of the heroines in The Birch Tree and The Beehive. The birch tree symbolises the ethereal, slender, elegant and fragile nature of Janica, while the white dove stands for Janica's pure soul aspiring towards heaven. The queen bee symbolises Stojanka's and later Ljubica's power and dominant position within the family. Nonetheless, Janica is a passive character and an object, whereas Stojanka is an active character who takes matters into her own hands and is thus a subject in her own right. Therefore, in the light of their characters' trajectories and the films' denouements, the iconography of The Birch Tree disempowers Janica due to her untimely death, while the iconography of The Beehive potentially empowers Stojanka due to an open ending that gives some hope that Stojanka may be pardoned. Nevertheless, it is not definite. The empowering effect is also diminished by the fact that Stojanka's story is mostly presented by a male narrator (whose voice initiates not only his retrospectives shown from objective perspective in third person, but sometimes of others, such as Ljubica's), instead of by Stojanka who is relegated to silence. In addition, Stojan$\mathrm{ka}$ is exposed to domestic violence from her husband, whereas Janica is not, but is instead neglected. The characters of Janica and Stojan$\mathrm{ka}$, taken together, indicate the entire tone of how women stood vis-à-vis the patriarchy in contemporary Yugoslavia - to borrow Haskell's words, 'from reverence to rape' (1987), since Janica is revered by 'holy' Joža and Stojanka is raped by Halil bey. In both films, only female characters are engaged in magic and stand for the impoverishment, scarcity, ignorance and backwardness of pre-socialist society.

Regardless of the gender ideologies behind the representations, both films are extremely valuable, because in the Yugoslav New Film movement, female characters were seldom given main roles. Most importantly, as I have argued, Babaja's and Popovićs analysed films regress into the past and refract real-life gender inequalities of a family domain from a bygone socialist present, therefore criticizing them.

\section{B I B L I O G R A P H Y}

Beganović D., Changing Fates: The Role of the Hero in Yugoslav Cinema in the Early and Late Sixties [in:] Retracing Images: Visual Culture After Yugoslavia, ed. D. Šuber, S. Karamanić, Leiden 2012, pp. $135-148$

"Black Waves, Red Horizons - New Yugoslav Film". Arsenal: Institut für film and videokunst e.V., 2015, accessed March 04

Blackwell M.J., The Seventh Seal (1956): Cinematic Form and Cultural Criticism, [in:] Film Analysis: A Norton Reader, ed. J. Geiger, R.L. Rutsky, New York 2005, pp. 528-549

Boglić M., Mit i antimit, Zagreb 1980

Bogojević M., The beauty of gender sin: politics of representation in Yugoslav auteur film, "ProFemina" 2011, pp. 255-262

Brinkema E., The fault lines of vision: Rashomon and The Man Who Left His Will on Film, [in:] Rape in Art Cinema, ed. D. Russel, New York 2010, pp. 27-40

Chakravarty S., Gender in transit: framing the cinema of migration, [in:] The Routledge Companion to Cinema and Gender, ed. K.L. Hole, D. Jelača, E.A. Kaplan, P. Petro, London, New York 2017, pp. 57-67 
Chivers S., "No place for sissies": gender, age, and disability in Hollywood, [in:] The Routledge Companion to Cinema and Gender, ed. K.L. Hole, D. Jelača, E.A. Kaplan, P. Petro, London, New York 2017, pp. $68-76$

Cox J., Digital Nature Photography, New York 2003

De Cuir G. Jr., Partisan "realism": representations of wartime past and state-building future in the cinema of socialist Yugoslavia, "Frames Cinema Journal" 2013, p. 4

Didron A.N., Christian Iconography; or, the History of Christian art in the Middle Ages, trans. E.J. Millington, London 1851

Doane M.A., Masquerade Reconsidered: Further Thoughts on the Female Spectator, "Discourse" 19881989, 11 (1), pp. 42-54

Doane M.A., The "woman's film": possession and address, [in:] Re-Vision: Essays in Feminist Film Criticism, ed. M.A. Doane, P. Mellencamp, L. Williams, Los Angeles 1984, pp. 67-82

Đorgović M., Panić A., Popović U., Ženska Strana/ Women's Corner, [in:] Exhibition Catalogue, Belgrade 2010

Favero P., Blessed be the good soldier: cinema, media and the manufacturing of nationhood in post 9/11 Italy, "Archivio Antropologico Mediterraneo" 2011, 13 (1), pp. 55-66

Fischer L., Feminist forms of address: Mai Zetterling's loving couples, [in:] The Routledge Companion to Cinema and Gender, ed. K.L. Hole, D. Jelača, E.A. Kaplan, P, Petro, New York 2017, pp. 36-46

Gage J., Color and Meaning: Art, Science, and Symbolism, Berkeley 1999

Gilić N., Uvodna bilješka, "Hrvatski filmski ljetopis" 2010, 16 (62), pp. 6-7

Grant B.K., Film Genre: From Iconography to Ideology, London 2007

Gudac-Dodić V., Položaj žene u Srbiji (1945-2000), [in:] Žene i deca: 4. Srbija u modernizacijskim procesima XIX i XX veka, ed. L. Perović, Beograd 2006, pp. $33-130$

Haskell M., From Reverence to Rape: The treatment of women in the movies, 2nd ed., Chicago 1987

Heckscher W.S., Art and Literature: studies in relationship, Baden-Baden 1994

Hole K.L., Jelača D., Kaplan E.A., Petro P., Introduction: Decentering feminist film studies, [in:] The Routledge Companion to Cinema and Gender, ed. K.L. Hole, D. Jelača, E.A. Kaplan, P. Petro, New York 2017, pp. 1-12

Johnston C., Women's cinema as counter-cinema, [in:] Feminism and Film, ed. A.E. Kaplan, New York 2000, pp. 22-33
Jovanović N., Gender and Sexuality in the Classical Yugoslav Cinema, 1947-1962, PhD, Gender Studies, Central European University 2014

Kaplan E.A., Motherhood and Representation: The mother in popular culture and melodrama, London 1992

Kaplan E.A., Women and Film: Both Sides of the Camera, London 2000

Krelja P., Breza - film za sva vremena, "Hrvatski filmski ljetopis" 2010, 16 (62), pp. 13-21

Krelja P., Opake žene jugoslavenskog filma, [in:] Knjiga o filmu: "Filmska kultura", 1957-1977, ed. F. Hanžeković, S. Ostojić, Zagreb 1979, pp. 409-416

Krijnen T., Van Bauwel S., Gender and Media: Representing, producing, consuming, communication and society, London 2015

Lesage J., The political aesthetics of the feminist documentary film, "Quarterly Review of Film Studies" 1978, 3 (4), pp. 507-523. doi: 10.1080/10509207809391421

Lóránd Z., The Feminist Challenge to the Socialist State in Yugoslavia, Cham 2018

Miller N., The Nonconformists: Culture, Politics, and Nationalism in a Serbian Intellectual Circle, 1944-1991, Budapest 2007

Morokvašić M., Being a woman in Yugoslavia: Past, present and institutional equality, [in:] Women of the Mediterranean, ed. M. Gadant, London 1986, pp. $120-138$

Novaković S., Vreme otvaranja, Novi Sad 1970

Novaković S., Tirnanić B., Dušan Makavejev: Negirati estetiku u korist života, "Polja" 1967, 13 (109), p. 6

O'Meara J., What "The Bechdel Test" doesn't tell us: examining women's verbal and vocal (dis)empowerment in cinema, "Feminist Media Studies 2016, 16 (6), pp.1120-1123, doi: 10.1080/14680777.2016.1234239

Panofsky A.L., From epistemology to the Avant-garde: Marcel Duchamp and the sociology of knowledge in resonance, „Sage Journals” 2003, vol. 20, nr 1, pp. 61-92

Pantelić I., Partizanke i antifašistički front žena Jugoslavije (1942-1953), "ProFemina" 2011, pp. 81-98

Papić Ž., Žarana Papić. Tekstovi 1977-2002. Belgrade 2012

Perić T., Tradicijska glazba i običaji Sjeverozapadne Hrvatske, Bachelor's Degree Bachelor's thesis, Odsjek za učiteljske studije, Sveučilište u Zagrebu - Učiteljski fakultet 2016

Petrović A., Novi film II (1965-1970): “Crni film”, Beograd 1988

Racic M., Do this year's best picture Oscar Nominees Pass the Bechdel Test? Revisiting an imperfect but useful litmus test in light of \#MeToo, "The New Yorker" 2018, last modified 3/3/2018, <https://www.newy- 
orker.com/culture/culture-desk/do-this-years-best-picture-oscar-nominees-pass-the-bechdel-test>, accessed: 31.03 .2018

Rajković Z., Narodni običaji okolice Donje Stubice, "Narodna umjetnost" 1974, 10 (1), pp. 153-214

Ramet S.P., In Tito's Time, [in:] Gender Politics in the Western Balkans: Women and society in Yugoslavia and the Yugoslav successor states, ed. S.P. Ramet, University Park 1999, pp. 89-106

Riviere J., Womanliness as a masquerade, [in:] Influential Papers from the 1920s, ed. R.D. Hinshelwood, London 2018, pp. 127-138, Original edition, 1929

Rožić R., Život je žilav - Janica je živa?!, "Hrvatski filmski ljetopis" 2010, 16 (62), pp. 22-24

Ryland J., Iconography, [in:] The Women's Companion to International Film, ed. A. Kuhn, S. Radstone, Berkeley 1990, pp. 212-212

Simić A., Machismo and cryptomatriarchy: power, affect, and authority in the traditional Yugoslav family, [in:] Gender Politics in the Western Balkans, ed. S.P Ramet, University Park 1999, pp. 11-30
Sklevicky L., Konji, žene, ratovi, Zagreb 1996

Slapšak S., Žensko telo u jugoslovenskom filmu: status žene, paradigma feminizma, [in:] Žene, slike, izmišljaji, edited by Branka Arsić, Beograd 2000, pp. 121-138

Stojanović D., Velika avantura filma, Beograd 1969

Vaquero M., A recurrent theme of the Spanish medieval epic: complaints and laments by noble women, [in:] Epic and History, ed. D. Konstan, K.A. Raaflaub, Chichester 2010, pp. 310-327

Woodside A.G., Case Study Research: Core Skills in Using 15 Genres, Bingley 2017

Zaharijević A., 'Women's Liberation', Četrdeset godina kasnije, "ProFemina" 2011, pp. 187-200

Zaharijević A., The Strange Case of Yugoslav Femiism: Feminism and Socialism in "the East", [in:] The Cultural Life of Capitalism in Yugoslavia: (post)socialism and its other, ed. D. Jelača, M. Kolanović, D. Lugarić, Cham 2017, pp. 263-284

Žižek S., The Metastases of Enjoyment: Six Essays on Woman and Causality, London 1994

Acknowledgements: I would like to thank my academic advisor Prof. Dr. Philippe Meers for his perpetual help with my research and this article. My gratitude goes beyond words to my dear colleagues Natalie Kowalik, Chernelle Lambert-Sebrechts and Ryan Pescatore Frisk for their generous and indispensable support with the proofreading. In addition, my heartfelt thanks goes to Paraskevi Olbricht, Robert Olbricht, Iva Jurišković and Đorđe Čekrlija. Also, I truly appreciate efforts of Images staff: Maciej Pietrzak, Patrycja Rojek, Joanna Pigulak, and Sabrina Haenze. Lastly, I am greatly indebted to Dr. Paolo Favero, Dr. Frederik Dhaenens, and Dr. Alex Forbes, whose constructive feedback enriched this article.

Funding: This work was supported by the University of Antwerp Research Fund [DOCPRO1 BOF] from September 2017 until August 2018. 